\title{
A method for Rearing Perch, Perca fluviatilis, Larvae Using Paramecium caudatum, Followed by Wild Zooplankton and Formulated Dry Feed in Combination With Adequate Tank Systems
}

\author{
Franz Lahnsteiner ${ }^{1} \&$ Manfred Kletzl $^{2}$ \\ ${ }^{1}$ Federal Agency for Water Management, Institute for Water Ecology, Fisheries and Lake Research, Mondsee, \\ Austria \\ ${ }^{2}$ Fishfarm Kreuzstein, Unterach, Austria \\ Correspondence: Franz Lahnsteiner, Federal Agency for Water Management, Institute for Water Ecology, \\ Fisheries and Lake Research, Scharfling 18, A-5310 Mondsee, Austria. E-mail: Franz.Lahnsteiner@baw.at
}

\author{
Received: April 26, 2018 \\ doi:10.5539/jas.v10n8p26 \\ Accepted: June 5, $2018 \quad$ Online Published: July 15, 2018 \\ URL: https://doi.org/10.5539/jas.v10n8p26
}

\begin{abstract}
The present study investigates methods for larviculture and fingerling production in the European perch, Perca fluviatilis. Perch larvae in the stage of first feeding were sensitive to many manipulations necessary in fish culture. Lowering and increasing the tank water level as required for cleaning and water renewal, water flow and aeration led to disturbed buoyancy or mortality in a distinct percentage of larvae. Paramecium caudatum, wild zooplankton containing $>70 \%$ copeopds, and formulated dry feed were used for first feeding in combination with flow through tanks or static tanks. For first feeding Paramecium caudatum in combination with a static tank system was optimal resulting in survival rates of circa $90 \%$ at 15 days post hatch (dph). Wild zooplankton was no optimal starter feed as perch fed non-selectively on any feed particle available. This resulted in moderate survival rates of circa 50\% at $15 \mathrm{dph}$. First feeding with formulated dry feed caused malformations (enlargement of swimbladders) and a high mortality of $>80 \%$. Weaning from Paramecium caudatum to formulated dry feed and to zooplankton was tested on 8-16 dph larvae. Perch accepted the new food type within 3 days. The optimal time point for zooplankton weaning was $12 \mathrm{dph}$. In this age larvae had developed a selective feeding behaviour, and fed mainly on nauplii and copepodites. Weaning to formulated dry feed was impossible as larvae developed malformations resulting in high mortality as described above. Weaning from wild zooplankton to formulated dry feed was possible for larvae $\geq 29 \mathrm{dph}$. No cannibalism was observed in the experiments. The method was also tested in large scale experiments resulting in a survival rate of $65 \pm 4 \%$, a total length of $45.0 \pm 7.2 \mathrm{~mm}$, and a body weight of $1097 \pm 293 \mathrm{mg}$ at $75 \mathrm{dph}$.
\end{abstract}

Keywords: Perca fluviatilis, larvae, Paramecium caudatum, zooplankton, formulated dry feed, malformation rate, survival rate, growth rate

\section{Introduction}

The European perch, Perca fluviatilis, is a species with high potential for aquaculture (Kestemont, Dabrowski, \& Summerfelt, 2015). At present the production of fingerlings adapted to formulated dry feed is one of the major bottlenecks for the intensification of its culture (Policar, Samarin, \& Mélard, 2015). The small larvae size, their sensitivity to different kinds of abiotic factors, and their dependence on specific high quality live food are considered as limiting factors (Policar, Samarin, \& Mélard, 2015).

At present perch larvae are reared to fingerlings using three different methods (Policar, Samarin, \& Mélard, 2015). (1) Pond culture with suitable-sized zooplankton is the traditional method. (2) Culture in mesocosm systems provides more controlled natural conditions. Feeding is performed starting with zooplankton (mainly rotifers) followed by Artemia nauplii and finally by formulated dry feed. (3) Under intensive conditions perch larvae are fed with Artemia nauplii or with formulated diets as starter feeds. Generally, survival rates of larvae to fingerling size are low for all three culture systems and range from 5 to 40\% (Policar, Samarin, \& Mélard, 2015).

Intensive culture of perch larvae under controlled conditions is an important goal to increase its production (Kestemont, Dabrowski, \& Summerfelt, 2015). However, this culture method still faces several problems: Failure in swim bladder inflation may lead to development of abnormalities and to increased mortality 
(Jacquemond, 2004). For first feeding Artemia nauplii are used (Mélard, Baras, Mary, \& Kestemont, 1996a; Vlavonou, Masson, \& Moreau, 1999; Kestemont, Xueliang, Hamza, Maboudou, \& Toko, 2003; Król \& Zieliński, 2015). However, due to their large size they are not optimal as they can be ingested only by a distinct percentage of larvae (Mélard, Baras, Mary, \& Kestemont, 1996a; Vlavonou, Masson, \& Moreau, 1999). Suboptimal feed results in decreased survival rates and size heterogeneity of developing fish. Further consequences are cannibalism, increased disease susceptibility, and highly variable culture success (Mélard, Baras, Mary, \& Kestemont, 1996; Mélard, Kestemont, \& Grignard, 1996; Król \& Zieliński, 2015). Perch larvae accept also formulated dry feed, but survival and growth rates are significantly lower than those obtained with Artemia nauplii (Tamazouzt, Leray, Escaffre, \& Terver, 1998; for review see Kestemont, Dabrowski, \& Summerfelt, 2015). To improve the culture success optimizations were made in aspects of rearing conditions. Tamazouzt, Chatai, and Fontaine (2000) demonstrated that highest growth in weight and length was obtained in tanks with light grey and white walls, which were strongly illuminated. Contrary, according to Jentoft, Øxnevad, Aastveit, and Andersen (2006) perch larvae grew significantly faster in black tanks than in gray tanks due to better prey contrast. Ribi (1992) reported that perch larvae survive better in diluted sea water than in fresh water. Cannibalism is a critical factor in perch culture. It could be decreased by high stocking density due to a confusion effect when the predator is confronted to a large number of targets (Baras, Kestemont, \& Mélard, 2003; Kestemont et al., 2003), by conditions resulting in homogeneous growth (Mélard, Baras, Mary, \& Kestemont, 1996b), and by regular size-sorting (Mélard, Baras, Mary, \& Kestemont, 1996b). Cannibalism was not related to the weaning age (Król \& Zieliński, 2015).

In summary, a practical method for fingerling production could not be established under aspects of economy, animal welfare and sustainability. Therefore, the present study has the aim to extend the knowledge on larviculture and fingerling production in the European perch, Perca fluviatilis. It investigates the effect of different kinds of formulated dry feeds and live feeds in combination with different rearing systems on the survival rate, growth rate, feed uptake rate, and malformation rate. Complementary, malformations are histologically investigated and water quality in the tested tank systems is analyzed. By combining suitable feed types and rearing systems a method for perch fingerling production under intensive conditions is developed and also tested under hatchery relevant large scale conditions.

\section{Material and Methods}

Egg ribbons of perch, Perca fluviatilis, were collected after natural spawning in ponds. The eggs were disinfected with $1000 \mathrm{ppm}$ formalin for $30 \mathrm{~min}$, and incubated in ground water warmed to $18{ }^{\circ} \mathrm{C}$ by adequate heating units. Water parameters are reported in Table 5. After hatching larvae were collected with measuring cups and defined numbers were stocked in the experimental tanks having similar water conditions (for determination of larvae numbers see 2.7.-Fish investigations).

\subsection{Collection and Processing of Zooplankton}

Live zooplankton was collected from wild populations from lake Mondsee with plankton nets (AquaTech, Kitzbühl, Austria). The nets were dredged floating behind a boat in a depth of 10-15 $\mathrm{m}$ and at a cruising speed of $0.5 \mathrm{miles} / \mathrm{h}$. The collection area and the dredging depth were adjusted depending on weather conditions and on occurrence of zooplankton organisms. Using a sieve netting procedure a $<200 \mu \mathrm{m}$ size fraction and a 200-400 $\mu \mathrm{m}$ size fraction were collected. The collected zooplankton was washed out of the nets into 201 buckets and diluted to a density of circa 100.000 organisms per litre. Five ml subsamples were collected in 2-day intervals and fixed in $4 \%$ formaldehyde. Zooplankton composition was determined by counting the number of nauplii, copepodites, Daphnia sp., Cyclops sp., Diaptomus sp. Cypris sp., rotifers, phytoplankton, and pollen (the latter occurred in zooplankton during the spring season, too). Organisms/particles are reported as percentile values of the total number of organisms/particles counted in the subsamples.

For preparation of zooplankton meal the $200-400 \mu \mathrm{m}$ size fraction was used. The water was drained away, ascorbic acid and tocopherol were added as antioxidants in final concentrations of $80 \mathrm{mg} / 100 \mathrm{~g}$ dry weight and $10 \mathrm{mg} / 100 \mathrm{~g}$ dry weight, respectively. The zooplankton was spread in a thin layer of $2-4 \mathrm{~mm}$ on cooking trays, dried at $80^{\circ} \mathrm{C}$ for 12 hours, and grinded to a powder.

\subsection{Paramecium caudatum Cultures}

A starter culture of Paramecium caudatum was obtained from a commercial supplier. Alfalfa medium was used as culture substrate (Detrich, Zon, \& Westerfield, 2009). Primary subcultures were made in 51 water. These were used for hatchery relevant follow-up subcultures in 501 tanks. All culture tanks were covered to avoid potential contamination with microorganisms. At a temperature of $20-23{ }^{\circ} \mathrm{C}$ it took 4-5 days to grow healthy cultures. Criteria for healthy cultures were Paramecium caudatum concentrations of 5-10 cells $/ \mathrm{ml}$ culture medium and 
clear water conditions not smelling rotten. Opposite would have indicated imbalanced bacterial growth due to high quantities of substrate. Circa 51 of the healthy cultures were daily used to start new subcultures. The rest of the Paramecium caudatum culture was harvested for larvae feeding. Tanks were illuminated with full spectrum lights with circa 300 lux and within $1 \mathrm{~h}$ Paramecium caudatum concentrated in clouds in the upper water areas. These clouds were sampled using measuring cups with a volume of 51 and added in the larvae rearing tanks. Alternatively the cells were collected also with $100 \mu \mathrm{m}$ plankton nets and added in the rearing tanks.

\subsection{Preparation of Formulated Dry Feed}

Two self-made starter feeds for fish larvae were tested. Both starter feeds consisted of low temperature fish meal, lactalbumin, salmon fish oil, soya lecithin, vitamin mix, and mineral mix (Lahnsteiner \& Kletzl, 2015a, 2015b). Additionally, starter feed 1 contained krill meal, starter feed 2 self-prepared zooplankton meal. The components were mixed together with water, and the dough mixture was extruded using a Caleva variable density screw extruder with axial configuration. Used die hole diameter was $1 \mathrm{~mm}$, die hole depth $10 \mathrm{~mm}$, and extrusion temperature $75^{\circ} \mathrm{C}$. Extrusion was performed at $50 \mathrm{rpm}$. The extrudate was dried at $80^{\circ} \mathrm{C}$ for $4 \mathrm{~h}$ and grinded in a corn mill to a particle size of $0.2 \mathrm{~mm}$. The declaration of the two starter feeds is shown in Table 1 .

Table 1. Composition of the formulated dry feed tested for first feeding of perch larvae

\begin{tabular}{lll}
\hline & FDF1 & FDF2 \\
\hline Protein, \% & 69.1 & 72.7 \\
Lipids, \% & 13.9 & 8.5 \\
Carbohydrate, \% & 4.9 & 4.9 \\
Calcium, \% & 1.2 & 1.2 \\
Phosphor, \% & 0.7 & 0.7 \\
Magnesium, \% & 0.3 & 0.3 \\
Fatty acid composition & & \\
$\sum$ saturated fatty acids, g/100 g DW & 4.6 & 2.8 \\
$\sum$ non saturated fatty acids, g/100 g DW & 8.2 & 4.6 \\
$\sum$ total fatty acids, g/100 g DW & 12.8 & 7.4 \\
$\sum \omega 3$ fatty acids, g/100 g DW & 4.2 & 1.9 \\
$\sum$ ( 6 fatty acids, g/100 g DW & 0.3 & 0.8 \\
Ratio $\omega 3: \omega 6$ & 13.7 & 2.3 \\
\hline
\end{tabular}

Note. DW: dry weight.

\subsection{Effect of Manipulations on Larvae Viability}

Larvae in the stage of first feeding were used and all experiments were made in triplicate. Forty larvae were stocked in 25 liter glass aquaria in $18{ }^{\circ} \mathrm{C}$ ground water: (1) In the control experiments the larvae were kept in aquaria without manipulations for $24 \mathrm{~h}$. (2) In the water change experiment larvae were kept in aquaria for $24 \mathrm{~h}$, too, but $50 \%$ of the tank water was changed $1 \mathrm{~h}$ after stocking. The water was drained away using a plastic tube with an inner diameter of $3 \mathrm{~mm}$ and filled up again using a similar tube. (3) In the tank aeration experiment larvae were kept in aquaria aerated with air stones via aquarium pumps for $24 \mathrm{~h}$. Aeration intensity was adjusted, that the air stones gave rise to 80-120 air bubbles/min which had a diameter $<2 \mathrm{~mm}$. (3) In the recirculation system experiment larvae were kept in aquaria tanks equipped with an under gravel filter system for $24 \mathrm{~h}$. The filter plates were covered with a 20-30 mm gravel layer with a particle diameter of 3-4 $\mathrm{mm}$ and connected to an external filter canister. The water flow within the tank was $0.01 \mathrm{~m} / \mathrm{min}$.

At the end of the experiments the number of live larvae without behavioral abnormalities, of live larvae with behavioral abnormalities, and of dead larvae was recorded. Larvae with behavioral abnormalities were also investigated on morphological abnormalities in a stereomicroscope at 20-40-fold magnification. Percentage of live larvae without behavioral abnormalities, percentage of live larvae with behavioral abnormalities, and percentage of dead larvae were calculated relative to the number of fish stocked in the tanks.

\subsection{Larvae First Feeding Experiments}

Feeding experiments of larvae started 4 days post hatch (dph) and were terminated $16 \mathrm{dph}$. Two types of formulated dry feed (Table 1) and the $<200 \mu \mathrm{m}$ size fraction of zooplankton were tested in circular flow through tanks. Paramecium caudatum feeding was tested in static tanks. Initial stocking density was 5 larvae/l water and 
tanks were illuminated with full spectrum lights with circa 200 lux for 16 hours in all experiments. All experiments were performed in triplicate.

The circular flow through tanks had a volume of 2001 . The water inlet and outlet were laterally at opposite sides of the tanks, the inlet at the bottom and the drainage at the surface. When supplied with $0.1 \mathrm{l} / \mathrm{sec}$ water the average water flow inside the tank was $0.01 \mathrm{~m} / \mathrm{min}$. The complete water renewal in the tank took circa $30 \mathrm{~min}$. The tanks were cleaned 2 times daily by draining away remnants of feed and dead larvae. The static systems were rectangular tanks with a volume of $200 \mathrm{l}$. Water was not changed and tanks were not aerated or cleaned.

Formulated dry feed was fed in quantities of $3 \mathrm{~g} /$ day using a band feeder. The $<200 \mu \mathrm{m}$ zooplankton fraction was fed 2 times daily in concentrations of 15-30 organisms/l tank water. Paramecium caudatum was added to the tanks in final concentrations of 500-1000 cells/l water. Its concentration was controlled daily and readjusted when necessary.

Larvae total length and body depth were measured at the onset and at the end of the experiments. The larvae feed uptake rate was determined 3 days after the start of the experiments. The larvae survival rate and larvae malformation rate were determined at the end of the experiment.

\subsection{Weaning of Larvae}

All weaning experiments were made in triplicate. The experimental setup is shown in Figure 1. In experiment 1 the weaning from Paramecium caudatum to the self-produced formulated dry feed 2 was tested (Figure 1a). This feed was successfully used for first feeding of larvae with undifferentiated digestive tracts in previous experiments (Lahnsteiner \& Kletzl, 2015a, 2015b, 2017). In experiment 2 the weaning from Paramecium caudatum to zooplankton was tested (Figure 1b), and in experiment 3 the weaning from Paramecium caudatum to zooplankton and finally to formulated dry feed (Figure 1c). In experiment 3 a commercially available starter feed for salmonid fry with a particle size of $300 \mu \mathrm{m}$ was used. As 24-34 dph perch have a fully differentiated digestive tract with stomach, pyloric caecae and intestine (Kestemont, Dabrowski, \& Summerfelt, 2015) this type of food was considered to be suitable for weaning. It contained $53 \%$ crude protein, $18 \%$ crude fat, $1 \%$ crude fibers, $1.15 \%$ phosphorus, 15000 I.E. vitamin A, 3000 I.E. vitamin D3, $300 \mathrm{mg}$ vitamin E, and immunostimulants. The digestible energy was $18.0 \mathrm{MJ}$.

The static system was a 2001 tank equipped with an under gravel filter. It consisted of filter plates which were covered with a circa 2-3 cm thick gravel layer (gravel size 3-6 mm) and which could be connected with an external canister filter. During Paramecium caudatum feeding and during feeding the $<200 \mu \mathrm{m}$ zooplankton fraction the under gravel filter was disconnected from the external canister filter to obtain static conditions. Canister filters were operated in tanks free of fish for full biological maturation of filter material. At the time points indicated in Figure 1 (change from Paramecium caudatum to formulated dry feed, change from the $<200$ $\mu \mathrm{m}$ zooplankton fraction to the $200-400 \mu \mathrm{m}$ zooplankton fraction) the under gravel filter plates were connected to the canister filters and water flow inside the tanks was adjusted to approximately $0.01 \mathrm{~m} / \mathrm{min}$. For weaning from zooplankton to formulated dry feed fish were transferred into 1501 circular tanks with the water inlet laterally at the surface and the water outlet centrally at the bottom. Water supply was $0.2 \mathrm{l} / \mathrm{sec}$ and the average flow rate inside the tank $0.02-0.04 \mathrm{~m} / \mathrm{min}$.

The survival rate, the malformation rate, the total length, and the body depth or body weight (depending on the age of the fish-see below) were determined at the beginning and at the end of the weaning procedure. The larvae feed uptake rate was determined 3 days after the start of weaning and at the end of weaning.

\begin{tabular}{|c|c|c|}
\hline \multicolumn{3}{|c|}{$\begin{array}{l}\text { Feeding: constant concentration of 500-1000 Paramecium caudatum/1 water } \\
\text { Tank system: static system without cleaning and aeration }\end{array}$} \\
\hline \multicolumn{3}{|c|}{$\downarrow$} \\
\hline Tank sy & $\begin{array}{l}\text { to formulated st } \\
\text { ding: band feeder } \\
\text { culation system w }\end{array}$ & vel filter \\
\hline$\swarrow$ & $\downarrow$ & $\searrow$ \\
\hline from $8-13 \mathrm{dph}$ & from $12-17 \mathrm{dph}$ & from $16-21 \mathrm{dph}$ \\
\hline
\end{tabular}

Figure 1a. Experiment 1: Weaning from Paramecium caudatum to formulated dry feed 2

Note. dph: days post hatch. 


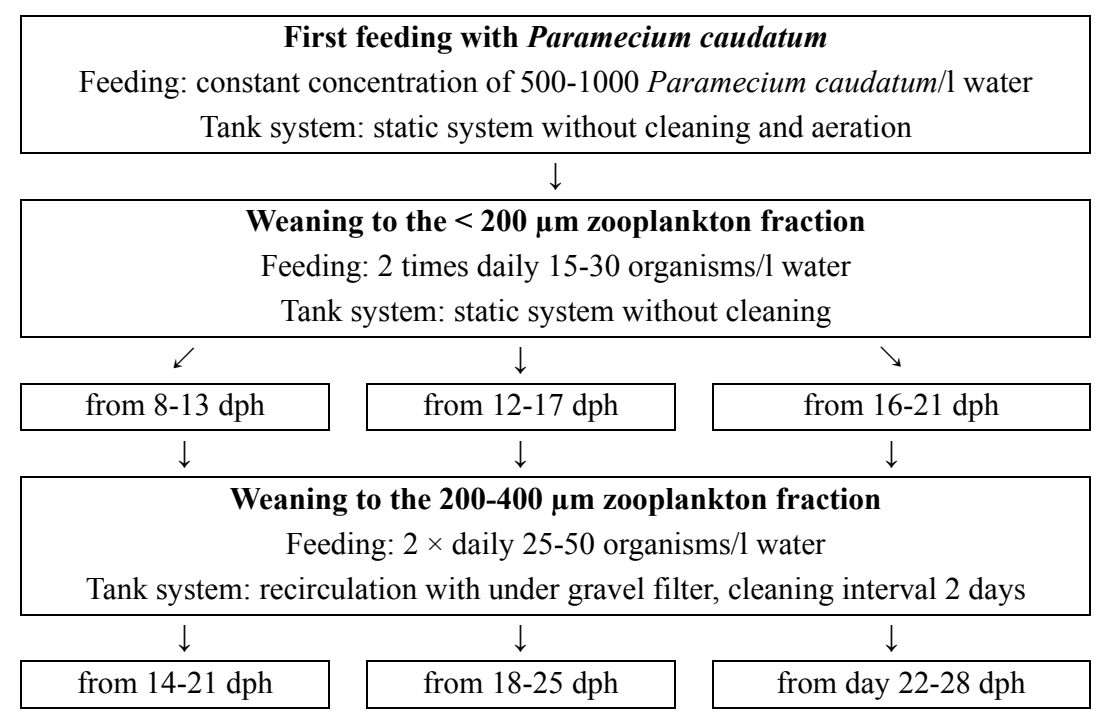

Figure 1b. Experiment 2: Weaning from Paramecium caudatum to zooplankton

Note. dph: days post hatch.

\begin{tabular}{|c|c|c|}
\hline \multicolumn{3}{|c|}{$\begin{array}{l}\text { First feeding with Paramecium caudatum in static system } \\
\text { Feeding: constant concentration of 500-1000 Paramecium/1 water } \\
\text { Tank system: static system without cleaning and aeration }\end{array}$} \\
\hline \multicolumn{3}{|c|}{$\downarrow$} \\
\hline $\begin{array}{r}\text { Wea } \\
\text { Fee } \\
\mathrm{T}\end{array}$ & $\begin{array}{l}<200 \boldsymbol{\mu m} \text { zoopla } \\
\text { es daily } 15-30 \text { org } \\
\text { static system witl }\end{array}$ & $\begin{array}{l}\text { tion } \\
\text { ater }\end{array}$ \\
\hline \multicolumn{3}{|c|}{$\downarrow$} \\
\hline \multicolumn{3}{|c|}{ from $12-17 \mathrm{dph}$} \\
\hline \multicolumn{3}{|c|}{$\downarrow$} \\
\hline \multicolumn{3}{|c|}{ Weaning to the 200-400 $\mu \mathrm{m}$ zooplankton fraction } \\
\hline \multicolumn{3}{|c|}{ Feeding: $2 \times$ daily $25-50$ organisms $/ 1$ water } \\
\hline \multicolumn{3}{|c|}{ Tank system: recirculation with under gravel filter, cleaning interval 2 days } \\
\hline$\swarrow$ & $\downarrow$ & $\searrow$ \\
\hline from $18-23 \mathrm{dph}$ & from $18-28 \mathrm{dph}$ & from 18-33 dph \\
\hline$\downarrow$ & $\downarrow$ & $\downarrow$ \\
\hline \multicolumn{3}{|c|}{ Transfer to circular flow through tanks } \\
\hline$\downarrow$ & $\downarrow$ & $\downarrow$ \\
\hline \multicolumn{3}{|c|}{ Weaning to formulated starter feed for trout fry } \\
\hline \multicolumn{3}{|c|}{$16 \mathrm{~h}$ continuous feeding with band feeder } \\
\hline \multicolumn{3}{|c|}{ Water supply: $0.21 / \mathrm{sec}$, cleaning: 2 times daily } \\
\hline$\downarrow$ & $\downarrow$ & $\downarrow$ \\
\hline from $24-50 \mathrm{dph}$ & from $29-55 \mathrm{dph}$ & from $34-60 \mathrm{dph}$ \\
\hline
\end{tabular}

Figure 1c. Experiment 3: Weaning from Paramecium caudatum to zooplankton and then to formulated dry feed Note. dph: days post hatch.

Content of the digestive tract was investigated in larvae weaned from Paramecium caudatum to the $<200 \mu \mathrm{m}$ zooplankton fraction 3 days after weaning. Analysis procedure is described in section 2.7.

\subsection{Hatchery Relevant Large Scale Experiments}

The developed rearing method was tested in a large scale experiment. This experiment was conducted in duplicate. Rectangular tanks $(5 \times 1.6 \times 0.6 \mathrm{~m}$, length $\times$ width $\times$ height $)$ were used which had the water inlet at one 
broadside and the water outlet at the other one. Tanks were filled to a height of $20 \mathrm{~cm}$ resulting in a water volume of 12001 and water was tempered to $17 \pm 2{ }^{\circ} \mathrm{C}$ using thermostat regulated heating coils. Tanks were stocked with quantities of 5 larvae/l (circa 6,000 larvae in total) and fed with Paramecium caudatum (cell concentration: 500-1000 cells/l water) from 3-11 dph. From 12-17 dph larvae were fed with the $<200 \mu \mathrm{m}$ zooplankton size fraction (organism concentration: 15-30 organisms /1 water, respectively) and from 18-28 dph with the 200-400 $\mu \mathrm{m}$ size fraction (organism concentration: $25-50$ organisms $/ 1$ water). Starting at $15 \mathrm{dph}$, tanks were supplied with $0.05 \mathrm{l} / \mathrm{sec}$ water and the water supply was gradually increased to $0.2 \mathrm{l} / \mathrm{sec}$ at $28 \mathrm{dph}$. At 29 dph larvae were transferred into 2001 circular tanks with the water inlet laterally at the surface and the water outlet centrally at the bottom. In the circular tanks the water supply was $0.2 \mathrm{l} / \mathrm{sec}$, the average flow rate inside the tank was $0.02-0.04 \mathrm{~cm} / \mathrm{min}$ and the stocking density 1000 fish (5 fish/l water). Starter feed for salmonid fry as described above was administered continuously using an automatic feeder for a period of $16 \mathrm{~h} /$ day. Initially it was administered in quantities of $0.75 \%$ of the body weight and from $35 \mathrm{dph}$ on in quantities of $1.25 \%$ of the body weight. Tanks were cleaned 2 times daily by draining away remnants of feed and dead larvae. The experiment was terminated at $75 \mathrm{dph}$. The larvae survival rate and the larvae total length and body weight were determined at $75 \mathrm{dph}$.

\subsection{Fish Investigations}

For determination of the survival rate 2 methods were used. For fish $<20$ dph five liters of tank water were collected after the larvae had been homogenously mixed in the tanks. The number of larvae was counted. Counting was repeated 2 times and the mean value of the determinations was taken to calculate the density of fish per liter water. Larvae numbers were extrapolated to the total water volume of the tanks. For fish $\geq 20 \mathrm{dph}$ all individuals were collected from a tank with a fine meshed hand net and counted. The survival rate was calculated as number of larvae surviving at the end of the experiment in relation to the number of larvae stocked at the onset of the experiment.

For determination of the malformation rate, the feed uptake rate, and for measurement of the total length and body depth 20 live fish were sampled. They were killed by prolonged exposure to $0.2 \%$ MS222. Larvae were photographed in a Motic stereomicroscope equipped with a digital camera at 20 to 40 fold magnification. Using the digitized micrographs the following parameters were evaluated: larvae with abnormalities in development (abnormalities in organs and vertebral column), larvae with food in the digestive tract (Paramecium caudatum visible as amorphous almost transparent mass, zooplankton visible as remnants of crustacean chitin shells, formulated dry feed visible as a brownish mass). The malformation rate was expressed as the number of larvae with malformations in relation to the total number of investigated fish and the food uptake rate as the number of fish with food in the intestine in relation to the total number of fish investigated.

For fish $<20$ dph the digitized micrographs were loaded in the Image J program and the larvae total length and body depth were measured. Details for measurement of body depth are shown in Figure 2a. Measurements were calibrated using an object micrometer. For fish $\geq 20$ dph the total length was determined with a ruler to the nearest $0.5 \mathrm{~mm}$ and the total weight with an analytical balance to the nearest $\mathrm{mg}$.

Relative growth in total length (RGTL) was calculated according to the formula,

$$
\mathrm{RGTL}=\frac{\mathrm{TL}_{\mathrm{c}}-\mathrm{TL}_{\mathrm{i}}}{\mathrm{TL}_{\mathrm{i}}} \times 100
$$

Where, $\mathrm{TL}_{\mathrm{e}}$ : mean final total length of 20 fish in a tank; $\mathrm{TL}_{\mathrm{i}}$ : mean initial total length of 20 fish in a tank.

Relative growth in body weight (RGBW) was calculated according to the formula,

$$
\mathrm{RGBW}=\frac{\mathrm{W}_{\mathrm{c}}-\mathrm{W}_{\mathrm{i}}}{\mathrm{W}_{\mathrm{i}}} \times 100
$$

Where, $\mathrm{W}_{\mathrm{e}}$ : mean final weight of 20 fish in a tank; $\mathrm{W}_{\mathrm{i}}$ : mean initial weight of 20 fish in a tank.

Relative growth in body depth (RGBD) was calculated according to the formula,

$$
\mathrm{RGBD}=\frac{\mathrm{BWI}_{\mathrm{c}}-\mathrm{BWI}_{\mathrm{I}}}{\mathrm{BWI}_{\mathrm{i}}} \times 100
$$

Where, $\mathrm{BWI}_{\mathrm{e}}$ : mean final body depth of 20 fish in a tank; BWI : mean initial body depth of 20 fish in a tank.

Wild zooplankton is inhomogeneous in aspects of organism/particle composition. Therefore the content of the digestive tract was analyzed to determine which organisms/particles were ingested by perch. Analysis was performed on $7 \mathrm{dph}$ perch fed with the $<200 \mu \mathrm{m}$ zooplankton size fraction and on $10 \mathrm{dph}$ perch weaned from Paramecium caudatum to the $<200 \mu \mathrm{m}$ zooplankton size fraction (start of weaning at $8 \mathrm{dph}$ ). From the first feeding experiment 10 live larvae and 10 freshly dead larvae were sampled from each of the 3 tanks. From the 
weaning experiment 10 live larvae were sampled from each of the 3 tanks. Larvae were killed as described, the digestive tract was removed by micro-preparatory techniques, cut open in its longitudinal direction and the main content of the digestive tract (food organisms/particles occurring in a frequency $>50 \%$ ) was investigated in a stereomicroscope at 40 -fold magnification. Food particles occurring in the digestive tract in a frequency $>50 \%$ were defined as main food type ingested by the investigated fish. The content of the digestive tract was defined as indifferent when no food organisms/particles occurred in a frequency $>50 \%$, or when the organisms/particles could not be classified. The percentage of larvae with nauplii, copepodites, ostracodes (Cypris sp.), algae, rotifers, or pollen as main food type in the digestive tract was calculated in relation to the total number of investigated larvae.

Malformations of perch were also analyzed histologically. Ten malformed fish were sampled from the first feeding experiment with self-produced formulated dry feed 2 after $10 \mathrm{dph}$ and fixed in $7 \%$ glutaraldehyde in 0.1 $\mathrm{mol} / \mathrm{l}$ cacodylate buffer ( $\mathrm{pH}$ 7.4). The fixative was washed out, the samples were decalcified in $0.4 \mathrm{~mol} / \mathrm{l}$ EDTA solution for $48 \mathrm{~h}$, dehydrated in a graded series of ethanol, and embedded in Technovit 7100 according to manufacturer instructions. 3-4 $\mu \mathrm{m}$ thick sections were cut with a microtome (Thermo Scientific HM325) and stained with $0.1 \%$ toluidine blue in $0.1 \mathrm{~mol} / \mathrm{l}$ phosphate buffer $(\mathrm{pH} 7.4)$. Sections were investigated in a light microscope at 400-1000-fold magnification.

\subsection{Water Analysis}

At 15 dph 1.51 water was collected from each of the tanks used for the first feeding experiments. pH was measured electrochemically with a standard electrode. $\mathrm{O}_{2}, \mathrm{NH}_{4}{ }^{+}$, and $\mathrm{KMnO}_{4}$ consumption were measured with chemical standard methods using adequate blanks and standard curves (Quevauviller \& Thompson, 2006).

Water bacteria were cultured on general purpose culture media (tryptic soy broth), on culture media specific for intestinal and fecal bacteria (MacConkey broth, eosin methylene blue broth), on cetrimide broth (specific for Pseudomonas sp.) and on Aeromonas enrichment medium (specific for Aeromonas sp.). Assay conditions were standardized in preliminary experiments in a way that microbiological growth was in the logarithmic growth phase at the time point of sampling. This was achieved by inoculating $1500 \mu \mathrm{l}$ tryptic soy broth with $10 \mu 1$ sample for $18 \mathrm{~h}$ and $1500 \mu \mathrm{l}$ of the other types of culture media with $100 \mu \mathrm{l}$ sample for $32 \mathrm{~h}$. Samples were aerobically inoculated in the growth media at $37^{\circ} \mathrm{C}$ under constant agitation. Bacterial densities were measured turbimetrically in a photometer at $540 \mathrm{~nm}$ versus a blank sample. Bacteria numbers were estimated using a standard curve with freeze dried Micrococcus luteus suspended in $0.75 \% \mathrm{NaCl}$ solution. Bacterial number determined in the specific culture media was added up and is reported as total bacteria concentration of the water samples. In Paramecium caudatum culture water were anaerobic conditions. Therefore bacteria were not investigated on the above described aerobic culture media.

\subsection{Statistics}

Percentage values used for statistical analysis were arcsin transformed. Metric data were tested for normality and processed without further transformation. Data from the first feeding experiments were analyzed with one way ANOVA. The rearing condition was the independent variable and the fish viability parameters were the dependent variables. Also data from the weaning experiment were analyzed with one way ANOVA. In this analysis weaning conditions were used as independent variable and viability and growth parameters of fish as dependent variables. Newman-Keuls method was used as post hoc test. Student t-test was used to analyze differences between live and dead larvae fed with the $<200 \mu \mathrm{m}$ zooplankton size fraction. SPSS software (Version 18.0) (USA) and SigmaPlot (Version 12.1) (U.S.A.) were used for statistical calculations.

\section{Results}

\subsection{Effects of Manipulation on Larvae Survival Rates}

All tested manipulations, i.e. tank water changes, tank aeration, and tank filtration caused a significant decrease in the percentage of live larvae without behavioral abnormalities and a significant increase in the percentage of larvae with behavioral abnormalities and in the percentage of dead larvae (Table 1). Larvae without behavioral abnormalities were distributed in the whole tank and swam in jerky movements. Larvae with behavioral abnormalities had reduced swimming activity, swam just beyond the water surface, and did not move in deeper water layers. However, they revealed no morphological abnormalities when investigated in the stereomicroscope. Dead larvae from the tank aeration, and tank filtration experiments had no morphological abnormalities, too. In the water renewal experiment $5 \%$ of the dead larvae had lesions in the musculature of the tail region. 
Table 2. Effect of different manipulation procedures on the viability of 3 dph perch larvae

\begin{tabular}{llll}
\hline Manipulation procedure & $\begin{array}{l}\text { \% live larvae without } \\
\text { behavioral abnormalities }\end{array}$ & $\begin{array}{l}\text { \% live larvae with } \\
\text { behavioral abnormalities }\end{array}$ & \% dead larvae \\
\hline Static aquaria without any manipulation for $24 \mathrm{~h}$ (control) & $97 \pm 2^{\mathrm{a}}$ & $0 \pm 0^{\mathrm{a}}$ & $3 \pm 1^{\mathrm{a}}$ \\
Static aquaria for $24 \mathrm{~h}$ with a water change after $1 \mathrm{~h}$ & $69 \pm 14^{\mathrm{b}}$ & $17 \pm 9^{\mathrm{b}}$ & $14 \pm 8^{\mathrm{b}}$ \\
Static aquaria with aeration for $24 \mathrm{~h}$ & $82 \pm 8^{\mathrm{b}}$ & $10 \pm 9^{\mathrm{b}}$ & $8 \pm 3^{\mathrm{c}}$ \\
Static aquaria with under-gravel re-circulation filter systems for $24 \mathrm{~h}$ & $76 \pm 8^{\mathrm{b}}$ & $9 \pm 6^{\mathrm{b}}$ & $15 \pm 6^{\mathrm{b}}$ \\
\hline
\end{tabular}

Note. Data are mean \pm standard deviation. $\mathrm{N}=3$ deriving from different tank replicates. Data superscripted by different letters are significantly different $(\mathrm{P} \leq 0.05)$.

\subsection{First Feeding of Perch Larvae}

\subsubsection{Dry Feed}

When feeding perch larvae with formulated dry feed 1 or 2 the feed uptake rate was $>80 \%$ on the $5^{\text {th }}$ dph (Table 2 ). At the end of the experiment ( $15 \mathrm{dph}$ ) the larvae survival rate was $12-16 \%$, the malformation rate $>75 \%$ and the relative increase in total length and in body depth was $20-30 \%$ (Table 2). No significant differences in viability and growth parameters were detectable between the two feed types. Malformed larvae revealed enlarged swim bladders and a compressed intestine. Malformed larvae and normally developed larvae are shown in Figures 2a and 2b. Malformed larvae swam just beneath the water surface and were unable to move in deeper water regions. Histological investigations revealed detachment of the swim bladder epithelium from the surrounding tissue (normally developed swimbladders see Figures $2 \mathrm{c}$ and $2 \mathrm{e}$, enlarged swimbladders see Figures $2 \mathrm{~d}$ and $2 \mathrm{f}$ ). Numerous spherical granules were found adhering to the swim bladder epithelium, in the swim bladder and in the surrounding tissue (Figure 2f). They had a diameter of $0.9 \pm 0.2 \mu \mathrm{m}$ and were interpreted as bacteria.

Under behavioral aspects the normally developed larvae concentrated in the outermost peripheral regions of the tank. When drifting in more central regions they exhibited a high swimming activity and were often swirled around due to turbulences. Larvae needed time periods of 5-10 $\mathrm{min}$ to reach again the peripheral regions.

\subsubsection{Live Zooplankton Feeding}

The $<200 \mu \mathrm{m}$ zooplankton fraction used for first feeding of perch larvae varied in its composition from day to day. Copepodites and nauplii contributed to circa $70 \%$ of the individual number (copepodites: $36.4 \pm 6.7$ [mean \pm S.D., $\mathrm{n}=7$ ], nauplii: $35.2 \pm 9.2 \%)$. The samples contained also Cypris sp. $(9.3 \pm 12.2 \%)$, rotifers $(4.3 \pm 4.7 \%)$, phytoplankton (diatoms $6.5 \pm 7.9 \%$, green algae: $5.1 \pm 4.7 \%$ ), and a low percentage of pollen ( $3.2 \pm 3.0 \%$ ).

When feeding the $<200 \mu \mathrm{m}$ zooplankton fraction to perch larvae the feed uptake rate was $>80 \%$ on the $5^{\text {th }} \mathrm{dph}$ (Table 2). The digestive tract of a larva without feed is shown in Figure $2 \mathrm{~g}$. After $15 \mathrm{dph}$, the larvae survival rate was $50 \%$, the larvae feed uptake rate $>90 \%$, and the malformation rate $12 \%$ (Table 3). Malformations concerned the enlargement of swim bladders as described above. Relative increase in total length and in body depth was the significantly higher than with formulated dry feed 1 or 2, or with Paramecium caudatum (Table 2). The swimming behavior of perch larvae was similar as described in section 3.2.1 for formulated dry feed.

Analysis of food organisms/particles in the digestive tract revealed a significant discrepancy between live and dead fish (Table 4). While the digestive tract of live fish contained $>50 \%$ nauplii and copepodites, the digestive tract of dead larvae contained $>50 \%$ Cypris sp., algae, pollen, and indifferent material (Figure 2h). 
Table 3. Effect of different feed types in combination with different tank systems on growth and viability parameters of perch larvae

\begin{tabular}{lllll}
\hline Larvae parameters & $\begin{array}{l}\text { Flow through, } \\
\text { FDF 1 }\end{array}$ & $\begin{array}{l}\text { Flow through, } \\
\text { FDF 2 }\end{array}$ & $\begin{array}{l}\text { Flow through, } \\
\text { Zooplankton }\end{array}$ & $\begin{array}{l}\text { Static, } \\
\text { Paramecium caudatum }\end{array}$ \\
\hline RGTL at 15 dph (\%) & $30.3 \pm 7.2^{\mathrm{a}}$ & $27.3 \pm 7.0^{\mathrm{a}}$ & $81.9 \pm 10.7^{\mathrm{b}}$ & $42.6 \pm 5.9^{\mathrm{c}}$ \\
RGBD at 15 dph (\%) & $21.1 \pm 11.9^{\mathrm{a}}$ & $20.0 \pm 9.2^{\mathrm{a}}$ & $165.6 \pm 14.0^{\mathrm{b}}$ & $27.8 \pm 5.0^{\mathrm{a}}$ \\
Survival rate at $15 \mathrm{dph}(\%)$ & $16 \pm 5^{\mathrm{a}}$ & $12 \pm 9^{\mathrm{a}}$ & $48 \pm 7^{\mathrm{b}}$ & $90 \pm 4^{\mathrm{c}}$ \\
Malformation rate at $15 \mathrm{dph}(\%)$ & $71 \pm 8^{\mathrm{a}}$ & $75 \pm 11^{\mathrm{a}}$ & $12 \pm 4^{\mathrm{b}}$ & $0 \pm 0^{\mathrm{c}}$ \\
Food uptake rate at $5 \mathrm{dph}(\%)$ & $86 \pm 6^{\mathrm{a}}$ & $85 \pm 4^{\mathrm{a}}$ & $83 \pm 8^{\mathrm{a}}$ & $88 \pm 4^{\mathrm{a}}$ \\
\hline
\end{tabular}

Note. dph: days post hatch, $3 \mathrm{dph}=$ date of first exogenous feeding. RGTL relative growth in total length, RGBD relative growth in body depth. Data are mean \pm standard deviation, $n=3$ deriving from different tank replicates. Data within a row superscripted by different letters are significantly different $(\mathrm{P} \leq 0.05)$.

Table 4. Main food type in the digestive tract of $7 \mathrm{dph}$ perch larvae fed with the $<200 \mu \mathrm{m}$ zooplankton size fraction

\begin{tabular}{lll}
\hline \multirow{2}{*}{ Main food type in the digestive tract } & \multicolumn{2}{c}{$\%$ larvae with a specific main food type in the digestive tract } \\
\cline { 2 - 3 } & Live larvae & Dead larvae \\
\hline Nauplii & $64 \pm 7^{\mathrm{a}}$ & $1 \pm 1^{\mathrm{b}}$ \\
Copepodites & $21 \pm 5^{\mathrm{a}}$ & $2 \pm 1^{\mathrm{b}}$ \\
Cypris sp. & $0 \pm 0^{\mathrm{a}}$ & $48 \pm 7^{\mathrm{b}}$ \\
Algae & $0 \pm 1^{\mathrm{a}}$ & $13 \pm 4^{\mathrm{b}}$ \\
Pollen & $0 \pm 0^{\mathrm{a}}$ & $12 \pm 5^{\mathrm{b}}$ \\
Indifferent material & $15 \pm 4^{\mathrm{a}}$ & $24 \pm 4^{\mathrm{b}}$ \\
\hline
\end{tabular}

Note. Data represent percentage of larvae with a specific main food type in the digestive tract and are mean \pm standard deviation, $\mathrm{n}=3$ from different tank replicates. Data superscripted by different letters are significantly different $(\mathrm{P} \leq 0.05)$.

\subsection{Weaning Experiments}

\subsubsection{Weaning From Paramecium caudatum to Formulated Dry Feed}

When 8-16 dph perch larvae were weaned from Paramecium caudatum to self-produced formulated dry feed $2>$ $80 \%$ of the larvae accepted dry feed within 3 days after the start of weaning (Table 6). Survival rate after a 6 days lasting weaning period was very low and not extending 10\% (Table 6). Therefore, the experiment stopped thereafter. Most of the larvae revealed malformations, i.e. significantly enlarged swim bladders as described above in the first feeding experiment with dry feed. For the normally developed larvae the relative increase in total length was $30-40 \%$ and the relative increase in body depth $15-20 \%$.

\subsubsection{Weaning From Paramecium caudatum to Zooplankton}

The $<200 \mu \mathrm{m}$ zooplankton fraction which was used as food during the first 6 days of the experiment had the following species composition: copepodites: 43.6 \pm 8.1 [mean \pm S.D., $n=3$ ], nauplii: $25.5 \pm 10.4$, ostracodes $(7.4 \pm 6.5 \%)$, rotifers $(5.0 \pm 3.4 \%)$, diatoms $(9.4 \pm 4.3 \%)$, green algae $(7.0 \pm 3.5 \%)$, and pollen $(2.1 \pm 1.5 \%)$. The $200-400 \mu \mathrm{m}$ fraction used for the following 8 days of the experiment contained $12.3 \pm 8.4 \%$ copepodites, $40.8 \pm 33.6 \%$ Daphnia sp., $26.1 \pm 23.7 \%$, Cyclops sp. and 20.9 $\pm 10.9 \%$ Diaptomus sp. 

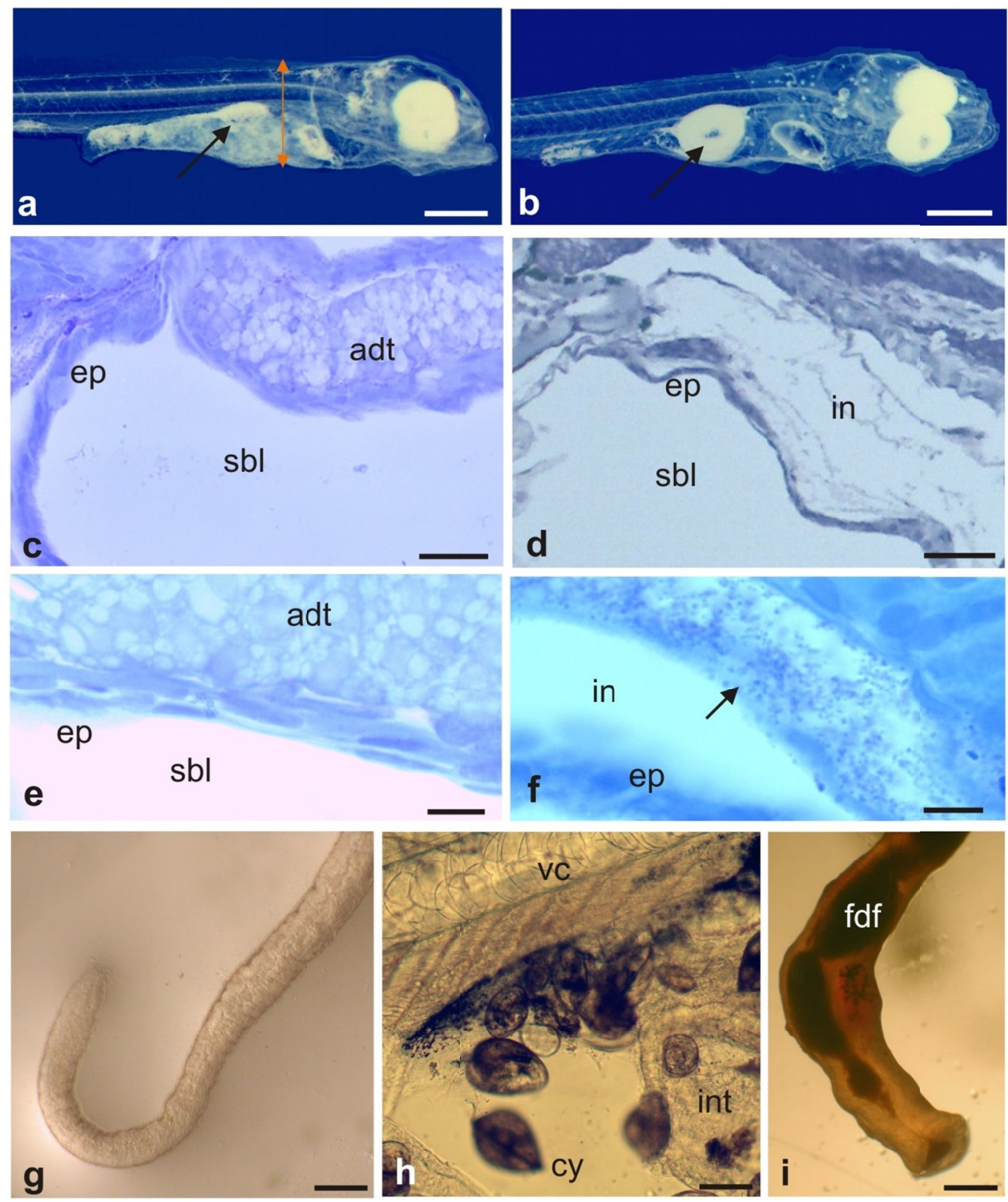

Figure 2. Stereomicroscopic and histological investigations on perch during the rearing experiments

Note. For Figures $2 \mathrm{a}$ and $2 \mathrm{~b}$ a digital clean-up was used to remove disturbing objects from the background and for structure enhancement.

Figure 2a: Normal swimbladder (arrow) of a 7 dph perch fed with Paramecium caudatum. Scale bar $=0.5 \mathrm{~mm}$. Orange arrow indicates the measurement points for determination of body depth; Figure 2b: Overinflated swim bladder (arrow) of a $7 \mathrm{dph}$ perch fed with formulated dry feed. Scale bar $=0.6 \mathrm{~mm}$; Figure 2c: Histology of an intact swimbladder showing the epithelium (ep) closely attached to the adipose tissue (adt). Sbl swim bladder lumen. Scale bar $=15 \mu \mathrm{m}$; Figure 2d: Histology of an enlarged swimbladder. The swim bladder epithelium (ep) is detached from the surrounding tissue. in interstitium, sbl swim bladder lumen. Scale bar $=35 \mu \mathrm{m}$; Figure 2e: Detail of the epithelium (ep) of a normal swim bladder. adipose tissue (adt), sbl swim bladder lumen. Histological section. Scale bar $=3.5 \mu \mathrm{m}$; Figure 2f: Detail of the epithelium (ep) of an enlarged swim bladder. sbl swim bladder lumen. Arrow shows spherical granules in the interstitium (in) Histological section. Scale bar $=$ $3.5 \mu \mathrm{m}$; Figure 2g: Digestive tract of a $7 \mathrm{dph}$ perch without food. Scale bar $=150 \mu \mathrm{m}$; Figure $2 \mathrm{~h}$ : Digestive tract of a 7 dph perch larvae containing Cypis sp. (feeding: $<200 \mu \mathrm{m}$ size fraction of zooplankton). Scale bar $=120$ $\mu \mathrm{m}$. cy Cypris, int intestine, vc vertebral column; Figure 2i: Digestive tract of a 26 dph perch containing formulated dry feed. Weaning from zooplankton to formulated dry feed (fdf) was started at $24 \mathrm{dph}$. Scale bar $=$ $100 \mu \mathrm{m}$. 
When 8-16 dph perch larvae were weaned from Paramecium caudatum to zooplankton $>80 \%$ of the fish

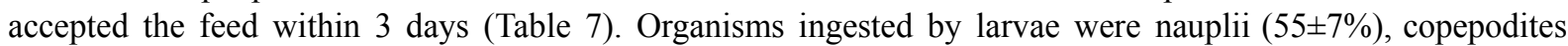
$(27 \pm 5 \%)$, and green algae $(2 \pm 1 \%)$. No ostracodes and pollen were found in the digestive tract. Perch larvae weaned to zooplankton had survival rates $>70 \%$ after a feeding period of 14 days (Table 7). Survival rates were highest when the $12 \mathrm{dph}$ larvae were weaned to zooplankton and significantly lower for younger $(8 \mathrm{dph})$ or older (16 dph) larvae (Table 7). The malformation rate was $<5 \%$ and the only type of malformation observed was the above described swim bladder enlargement.

The relative increase in total length was similar for larvae weaned from Paramecium caudatum to zooplankton at 8,10 , and $12 \mathrm{dph}$ (Table 7). The relative increase in body depth was significantly higher for larvae weaned at 10 dph than for larvae weaned at 8 and 12 dph (Table 7).

Table 5. Chemical parameters of fresh ground water, of Paramecium caudatum culture water, and of water from the different combinations of tank and food systems used for first feeding of larvae

\begin{tabular}{|c|c|c|c|c|c|}
\hline & $\mathrm{pH}$ & $\mathrm{O}_{2}, \mathrm{mg} / \mathrm{l}$ & $\mathrm{NH}_{4}^{+}, \mathrm{mg} / \mathrm{l}$ & $\begin{array}{l}\mathrm{KMnO}_{4} \text { consumption, } \\
\mathrm{mg} / \mathrm{l}\end{array}$ & $\begin{array}{l}\text { Total bacteria mass, } \\
\text { cells } \times 10^{9} / \mathrm{ml}\end{array}$ \\
\hline Ground water (control) & $7.85 \pm 0.02^{\mathrm{a}}$ & $10.7 \pm 0.2^{\mathrm{a}}$ & $0.002 \pm 0.001^{\mathrm{a}}$ & $4.7 \pm 0.2^{\mathrm{a}}$ & $0.1 \pm 0.1^{\text {a }}$ \\
\hline P. caudatum culture water & $7.55 \pm 0.20^{\mathrm{a}}$ & $0.0^{\mathrm{b}}$ & $11.10 \pm 4.37^{\mathrm{b}}$ & $236.5 \pm 45.0^{\mathrm{b}}$ & n.i. \\
\hline Flow through, FDF 1 (after $15 \mathrm{dph}$ ) & $7.98 \pm 0.02^{\mathrm{b}}$ & $8.6 \pm 0.2^{\mathrm{a}}$ & $0.040 \pm 0.005^{\mathrm{c}}$ & $12.3 \pm 0.6^{\mathrm{c}, \mathrm{d}}$ & $3.81 \pm 0.54^{\mathrm{c}}$ \\
\hline Flow through, FDF 2 (after $15 \mathrm{dph}$ ) & $8.00 \pm 0.01^{\mathrm{b}}$ & $8.5 \pm 0.2^{\mathrm{c}}$ & $0.047 \pm 0.012^{\mathrm{d}, \mathrm{c}}$ & $11.5 \pm 0.7^{\mathrm{c}}$ & $3.91 \pm 0.63^{\mathrm{c}}$ \\
\hline Flow through, zooplankton (after $15 \mathrm{dph}$ ) & $8.02 \pm 0.04^{\mathrm{b}}$ & $8.7 \pm 0.2^{\mathrm{c}}$ & $0.041 \pm 0.005^{\mathrm{c}}$ & $10.5 \pm 0.8^{\mathrm{c}}$ & $3.35 \pm 0.43^{\mathrm{c}}$ \\
\hline Static, P. caudatum (after $15 \mathrm{dph}$ ) & $8.21 \pm 0.03^{\mathrm{c}}$ & $8.1 \pm 0.3^{\mathrm{c}}$ & $0.054 \pm 0.006^{\mathrm{d}}$ & $14.9 \pm 3.1^{\mathrm{d}}$ & $3.03 \pm 0.49^{\mathrm{c}}$ \\
\hline
\end{tabular}

Note. Data are mean \pm standard deviation, $\mathrm{n}=3$ (from 3 tank replicates). N.i. not investigated. Total bacteria mass is the sum of bacteria mass grown on Eosin Methylene blue, McConcey, Cetrimide, Tryptic soy, and Aeromonas broth. Data superscripted by different letters are significantly different $(\mathrm{P} \leq 0.05)$.

Table 6. Weaning of 8-16 dph perch from Paramecium caudatum to formulated dry feed and its effect on viability and growth parameters

\begin{tabular}{llll}
\hline \multirow{2}{*}{ Larvae parameters } & \multicolumn{3}{c}{ Duration of experiment } \\
\cline { 2 - 4 } & $8-13 \mathrm{dph}$ & $12-17 \mathrm{dph}$ & $16-21 \mathrm{dph}$ \\
\hline RGTL at the end of the experiment (\%) & $37.6 \pm 3.8$ & $34.3 \pm 5.8$ & $35.6 \pm 6.3$ \\
RGBD at the end of the experiment (\%) & $17 \pm 2.1$ & $20.0 \pm 1.7$ & $18.2 \pm 2.0$ \\
Survival rate at the end of the experiment (\%) & $10.2 \pm 6.5$ & $6.2 \pm 6.5$ & $4.3 \pm 4.0$ \\
Malformation rate at the end of the experiment (\%) & $95 \pm 5$ & $91 \pm 8$ & $96 \pm 4$ \\
Food uptake rate 3 d after start of weaning (\%) & $83 \pm 8$ & $85 \pm 7^{\text {a }}$ & $82 \pm 8$ \\
\hline
\end{tabular}

Note. dph: days post hatch. Data are mean \pm standard deviation, $\mathrm{n}=3$ deriving from different tank replicates. RGTL relative growth in total length, RGBD relative growth in body depth. Data are not significantly different (P > $0.05)$.

\subsubsection{Weaning From Zooplankton to Formulated Dry Feed}

When 24-34 dph perch larvae were weaned from zooplankton to formulated dry feed $>85 \%$ of the larvae accepted dry feed within 3 days (Table 8, Figure 2i). The survival rate at the end of the experiment was significantly lower when perch were weaned to formulated dry feed after 27 dph than when they were weaned after 29 or $34 \mathrm{dph}$ (Table 8). Malformation rate was $<2 \%$ in all experiments. The relative increase in total length and in body weight was significantly higher for larvae weaned at $29 \mathrm{dph}$ and at $34 \mathrm{dph}$ than for larvae weaned at 24 dph (Table 8).

\subsection{Large Scale Experiment on Rearing}

In a large scale experiment the survival rate of perch was $61 \pm 4 \%$ at $75 \mathrm{dph}$. At the end of the experiment perch had a total length of $45.0 \pm 7.2 \mathrm{~mm}$ and a body weight of $1097 \pm 293 \mathrm{mg}$. 
Table 7. Weaning of 8-16 dph perch from Paramecium caudatum to live zooplankton and its effect on larvae viability

\begin{tabular}{|c|c|c|c|}
\hline \multirow{2}{*}{ Larvae parameters } & \multicolumn{3}{|c|}{ Duration of experiment } \\
\hline & $8-21 \mathrm{dph}$ & $12-25 \mathrm{dph}$ & $16-29 \mathrm{dph}$ \\
\hline RGTL at the end of the experiment (\%) & $62.2 \pm 7.0^{\mathrm{a}}$ & $70.7 \pm 7.4^{\mathrm{a}}$ & $67 \pm 6.7^{\mathrm{a}}$ \\
\hline RGBD at the end of the experiment (\%) & $330.0 \pm 13.5^{\mathrm{a}}$ & $350.0 \pm 14.4^{\mathrm{b}}$ & $327.3 \pm 13.3^{\mathrm{a}}$ \\
\hline Survival rate at the end of the experiment $(\%)$ & $65.1 \pm 6.4^{\mathrm{a}}$ & $83.3 \pm 8.2^{b}$ & $62.6 \pm 8.2^{\mathrm{a}}$ \\
\hline Malformation rate at the end of the experiment (\%) & $4 \pm 4^{\mathrm{a}}$ & $3 \pm 3^{a}$ & $2 \pm 2^{\mathrm{a}}$ \\
\hline Food uptake rate $3 \mathrm{~d}$ after start of weaning (\%) & $86 \pm 5^{\text {a }}$ & $89 \pm 4^{\mathrm{a}}$ & $84 \pm 8^{\text {a }}$ \\
\hline
\end{tabular}

Note. Larvae were fed with the 100-200 $\mu \mathrm{m}$ zooplankton fraction for 6 days and thereafter with the $200-400 \mu \mathrm{m}$ fraction for 8 days. dph: days post hatch, RGTL relative growth in total length, RGBD relative growth in body depth. Data are mean \pm standard deviation, $\mathrm{n}=3$ deriving from different tank replicates. Data superscripted by different letters are significantly different $(\mathrm{P} \leq 0.05)$.

Table 8 . Weaning of 24-34 dph perch from live zooplankton feed to formulated dry feed and its effect on larvae viability

\begin{tabular}{|c|c|c|c|}
\hline \multirow{2}{*}{ Larvae parameters } & \multicolumn{3}{|c|}{ Duration of experiment } \\
\hline & $24-50 \mathrm{dph}$ & $29-55 \mathrm{dph}$ & $34-60 \mathrm{dph}$ \\
\hline RGTL at the end of the experiment (\%) & $89.5 \pm 9.4^{\mathrm{a}}$ & $96.8 \pm 10.4^{\mathrm{a}}$ & $100.4 \pm 9.5^{\mathrm{a}}$ \\
\hline RGBW at the end of the experiment $(\%)$ & $316.7 \pm 15.0^{\mathrm{a}}$ & $398.2 \pm 14.9^{b}$ & $388.8 \pm 12.6^{\mathrm{a}}$ \\
\hline Survival rate at the end of the experiment $(\%)$ & $53 \pm 12^{\mathrm{a}}$ & $69 \pm 6^{\mathrm{b}}$ & $67 \pm 11^{b}$ \\
\hline Malformation rate at the end of the experiment $(\%)$ & $0.7 \pm 0.4^{\mathrm{a}}$ & $1.5 \pm 0.5^{b}$ & $1.3 \pm 0.2^{b}$ \\
\hline Food uptake rate $3 \mathrm{~d}$ after start of weaning (\%) & $85 \pm 8^{\text {a }}$ & $87 \pm 8^{\mathrm{a}}$ & $87 \pm 7^{\text {a }}$ \\
\hline
\end{tabular}

Note. dph: days post hatch, RGTL relative growth in total length, RGBW relative growth in body weight. Data are mean \pm standard deviation, $\mathrm{n}=3$ deriving from different tank replicates. Data superscripted by different letters are significantly different $(\mathrm{P} \leq 0.05)$.

\section{Discussion}

The study demonstrated that perch larvae in the stage of first feeding are sensitive to many manipulations necessary in fish culture. Lowering and increasing the tank water level as required for cleaning and water renewal, water flow and aeration can disturb larvae buoyancy or cause injury or death of larvae possibly due to changes in hydrostatic pressure, turbulences, or mechanical forces. The perch is a physoclistous fish and the initial inflation of the swimbladder and the closure of the pneumatic duct occur at 6-12 dph (Eglof, 1996; Policar, Samarin, \& Mélard, 2015). Woolley and Qin (2010) suggested that larvae might be especially vulnerable to changes in hydrostatic pressure during the period of swimbladder development and differentiation. Rapid changes in hydrostatic pressure might occur when larvae are caught in upwelling water flows and drawn to the surface (Woolley \& Qin, 2010). Also in nature perch larvae select habitats with minimal water flow and are sensitive to turbulences and increased water flow (Treasurer, 1990; Kratochvil et al., 2008). On the other hand small-scale water turbulences might be advantageous in food-limited environments as they enhance the contact rate between fish larvae and their prey (Lewis \& Pedley, 2001).

First feeding of perch larvae is a critical step under intensive culture conditions (Hamre, Yúfera, Rønnestad, Boglione, Conceição, \& Izquierdo, 2013). The present study demonstrated that for first feeding a static water system without aeration and a homogenous, small-sized live food are optimal. This hypothesis bases on the following two observations. (1) Only in the static system larvae showed their natural swimming behaviour. They swam free in the water in jerky movements as also observed in their natural habitats (Treasurer, 1990; Kratochvil et al., 2008). Contrary, in the flow through tanks larvae crowded peripherally close to the tank walls. These peripheral regions probably have the lowest water flow due to friction forces between tank wall and fluid (Munson, Huebsch, \& Rothmayer, 2012). (2) Larvae did not tolerate formulated dry feed as starter feed. Also wild zooplankton was not optimal. Zooplankton is a mixture of different organisms and particles and larvae fed non-selectively on any organism/particle available. From these experiments it was concluded that a homogenous live feed was necessary as starter feed for perch larvae. Paramecium caudatum fulfilled the necessary criteria as it had an adequate size (length 120-220 $\mu \mathrm{m}$, width 60-120 $\mu \mathrm{m}$-Fokin, 1997) to be ingested by perch larvae, 
which mouth size is $0.35 \mathrm{~mm}$ (Policar, Samarin, \& Mélard, 2015). However, growth of perch larvae fed with Paramecium caudatum was moderate in comparison to zooplankton, indicating a decreased nutritional value. Paramecium caudatum has been used successfully for first feeding of different species of ornamental fish larvae with a mouth size too small to ingest crustacean species (Copepoda, Anostraca, Cladocera) (Borla, Palecek, Budick, \& O’Malley, 2002; Andrews, 2011) and for experimental fish (e.g. Danio rerio-Detrich, Zon, \& Westerfield, 2015). Müller et al. (2012) raised hybrids between Sander lucioperca and Sander volgensis successfully with live Paramecium sp. as starter feed. As Paramecium caudatum survives in the fish tanks for unlimited time periods no cleaning and manipulation procedures are necessary (Andrews, 2013). As a disadvantage also bacteria may be introduced into the fish tanks together with the culture medium (Peterson, Ferguson, Watral, Mutoji, Ennis, \& Kent, 2013) and the culture water is inadequate for fish larvae in aspects of $\mathrm{O}_{2}$ and $\mathrm{NH}_{4}$ concentrations. Therefore, accurate monitoring of tank water quality is necessary when using Paramecium caudatum as larvae feed. Rotifers are an adequate, homogenous small sized live feed for fish larvae, too (Lubens, Zmora, \& Barr, 2001; Shiri Harzevili, De Charleroy, Auwerx, Vught, Van Slycken, Dhert, \& Sorgeloos, 2003; Park, Puvanendran, Kellett, Parris, \& Brown, 2006). However, rotifers are elaborative to culture and require microalgae as food organisms (Lubens, Zmora, \& Barr, 2001; Shiri Harzevili, De Charleroy, Auwerx, Vught, Van Slycken, Dhert, \& Sorgeloos, 2003; Park, Puvanendran, Kellett, Parris, \& Brown, 2006). Also organic loads and bacterial concentrations can be high in rotifer cultures (Dhont, Dierckens, Støttrup, Van Stappen, Wille, \& Sorgeloos, 2013).

Formulated dry feed 2 was successfully used for first feeding of different salmonid species which could not be reared with commercially available starter feed (e.g. Thymallus thymallus, Coregonus maraena, Coregonus atterensis) (Lahnsteiner \& Kletzl, 2015a, 2015b). Formulated dry feed 1 was modified in fatty acid composition and in the ratio of $\omega 3: \omega 6$ unsaturated fatty acids as these are species specific parameter in fish larvae nutrition (Hamre, Yúfera, Rønnestad, Boglione, Conceição, \& Izquierdo, 2016). When feeding these formulated dry feeds to larvae, they developed enlarged swimbladders leading to highly positive buoyancy. Histologically, the swim bladder revealed tissue destructions and indications for the occurrence of coccus-like bacteria. However, tank water did not significantly differ from other rearing regimes in aspects of qualitative and quantitative composition of bacteria when using tryptic soy broth, MacConkey broth, eosin methylene blue broth, cetrimide broth and Aeromonas enrichment medium as culture media. Theoretically, the formulated dry feed might favor the growth of specific species of pathogenic bacteria leading to disturbance of gas regulation and finally to swimbladder overinflation. Also the indigestibility of formulated dry feed might be related with swimbladder overinflation. However, these suggestions are speculative at present and require further investigations. A similar incidence of swim bladder overinflation was observed in larvae and juveniles of Lota lota and also in this species the reasons remained unknown (Rekecki et al., 2016). Failure in swim bladder inflation has been reported also for larvae of several marine species as Gadhus morhua (Grotmol, Kryvi, \& Totlan, 2005), Latris lineata (Trotter, Pankhurst, \& Hart, 2001) and Dicentrarchus labrax (Peruzzi, Westgaard, \& Chatain, 2007) under intensive culture conditions. In Gadhus morhua it has been claimed that larvae are hypersensitive to moderate levels of gas super-saturation (< $119 \%$ total gas pressure) (King \& Nardi, 2002), a parameter which can be excluded in the present experiments as fish fed with live feed did not develop swim bladder hyperinflation and gas oversaturation was not detected in unpublished measurement. Also in previous experiments survival rates were low when using formulated dry feed for first feeding of perch larvae similar as for pikeperch larvae (Ostaszewska, Dabrowski, Czumińska, Olech, \& Olejniczak, 2005; for review see Kestemont, Dabrowski, \& Summerfelt, 2015).

Copepod species and in particular their juvenile forms (nauplii and copepodites) have been demonstrated to be a nutritionally adequate live prey for rearing the larvae of many teleost fish species (Støttrup, 2003; Busch, Falk-Petersen, Peruzzi, Rist, \& Hamre, 2010; Busch, Peruzzi, Tonning, \& Falk-Petersen, 2011). Although the zooplankton used for feeding of perch larvae in the present study contained circa $70 \%$ nauplii and copepodites, analysis of the content of the digestive tract demonstrated that larvae fed non-selectively on any available particle which could be swallowed. Live larvae with significant growth fed mainly on nauplii and copepodites, while dead larvae fed on Cypris sp., algae, pollen, and indifferent material. Cypris sp. seemed indigestible for perch larvae as they were structurally still intact and alive in the terminal portion of the digestive tract. Live passage of ostracodes through teleost fish, amphibian and mammalian digestive tracts has been described in different studies (Aarnio \& Mattila, 2000; Lopez, Gonçalves, Mantovani, \& Rios, 2002). Algae, pollen, and indifferent material must be assumed to have inadequate nutritional value. Many experiments and culture protocols use Artemia nauplii for first feeding of perch larvae. However, larvae survival rate is variable and growth inhomogeneous, as Artemia nauplii are too large and can be ingested only by $60-70 \%$ of the larvae (Mélard, Baras, Mary, \& Kestemont, 1996a; Vlavonou, Masson, \& Moreau, 1999). Artemia has also a limited life span of 4-6 h in fresh water (Browne, Sorgeloos, \& Trotman, 1991) and therefore tank manipulations and 
cleaning procedures are necessary. In nature rotifers are the dominant first food of perch larvae and thereafter they feed on copepods (Treasurer, 1990; Kratochvil et al., 2008; Skrzypczak, Mamcarz, Kujawa, Kucharczyk, \& Furgala-Selezniow, 1998). Rotifers could not be detected in the digestive tract in the present study. Possibly they could not be identified and represent the food components reported as indifferent material. Also in other species as Elacatinus lori, and E. colini the Artemia nauplii were not a suitable prey, but feeding with rotifers followed by wild zooplankton was optimal in aspects of survival and growth of larvae (Majoris, Francisco, Atema, \& Buston, 2018).

The weaning experiments demonstrated that perch larvae did not refuse a new food type or had to be trained to a new food type by co-feeding procedures as described for different other fish species (Dicentrarchus labrax-Cahu \& Zambonino Infante, 1994; Elacatinus puncticulatus-Pedrazzani, Pham, Lin, \& Neto, 2014; Sparus aurata-Pantazis, Benekos, \& Papadomichelakis, 2014; Lota lota-Lahnsteiner \& Kletzl, 2017). Perch in an age of 8-34 dph accepted a new food type within 3 days. However, weaning from Paramecium caudatum to formulated dry feed was impossible. Similar as discussed above for the first feeding experiments, larvae developed strongly positive buoyancy due to enlarged swimbladders and finally died. Contrary, perch larvae could be successfully weaned from Paramecium caudatum to zooplankton as 10-18 dph larvae had developed a selective feeding behaviour and fed mainly on nauplii and copepodites. The experiments demonstrated that too early weaning was associated with increased mortality. Possibly, the selective feeding behavior was not fully developed at this time point. Also too late weaning resulted in increased mortality. This may be due to the fact that prolonged feeding with Paramecium caudatum resulted in growth stagnation probably as Paramecium caudatum was inadequate for more developed fish. Subsequently, prolonged Paramecium caudatum feeding might result in weakened fish with nutrition deficient which cannot be fully compensated after weaning.

Weaning from zooplankton to formulated dry feed was possible for perch $\geq 29 \mathrm{dph}$. In this age feeding with formulated dry feed did not induce swimbladder overinflation as in earlier development stages. Fish had differentiated a functional stomach, pyloric caecae, and a fully functional intestine which might facilitate digestion of dry feed (Kestemont, Dabrowski, \& Summerfelt, 2015). Flow through tanks used for weaning experiments had also higher water flow and cleaning efficiency than tanks used for first feeding experiments. This might reduce the growth of potentially pathogenic bacteria which could be associated with swimbladder enlargement. When younger fish $(24 \mathrm{dph})$ were weaned from zooplankton to formulated dry feed mortality was increased. Possible reasons might be the immaturity of the digestive tracts or the inability to tolerate flow through conditions.

Published weaning methods for perch and pike perch differ: Król and Zieliński (2015) weaned perch from Artemia to formulated dry feed after 14 days and Jentoft, Øxnevad, Aastveit, and Andersen (2006) after 28 days. Policar, Samarin, and Mélard (2015) described weaning as extended period of co-feeding Artemia and formulated dry feed from 7-30 dph during which Artemia is progressively replaced by formulated dry feed. According to the method of Szkudlarek and Zakęś (2007) for first feeding of pike perch a mixed feed of Artemia nauplii and artificial feed is useful which is replaced solely by dry feed after $14 \mathrm{dph}$. Kestemont, Xueliang, Hamza, Maboudou, and Toko (2007) described that weaning of pike perch from Artemia to formulated dry feed is possible between 12 and 19 dph with a varying mortality rate due to cannibalism.

The present large scale experiments demonstrated that the here described perch rearing method was also applicable in practice with final survival rates of $61 \pm 4 \%$ at $75 \mathrm{dph}$. These are one of the highest survival rates ever reported for intensive rearing of perch. Finally, it should be stressed that no cannibalism was observed in the present experiments as described in earlier studies. Fish develop cannibalistic behavior when growth is inhomogeneous (Baras \& Jobling, 2002). This could be avoided by the feeding sequence with Paramecium caudatum, zooplankton, and formulated dry feed. For culture purposes adaptions of the method in aspects of tank form, special tank refuge structures for larvae, and heating systems might be beneficial to obtain still more robust methods. Future studies might also bring a solution for direct weaning from Paramecium caudatum to formulated dry feed which could significantly facilitate the costs and labor of perch larvae production.

\section{Acknowledgements}

The authors are grateful to the team of the fish farm Kreuzstein for support in fish keeping and to Elias Lahnsteiner for laboratory works.

\section{References}

Aarnio, K., \& Mattila, J. (2000). Predation by juvenile Platichthys flesus (L.) on shelled prey species in a bare sand and a drift algae habitat. Hydrobiologia, 440, 347-355. https://doi.org/10.1023/A:1004112304096 
Andrews, B. (2011). Ornamental fish farming: Production methods. Melbourne, Australia. Retrieved from http://www.ornamentalfishfarming.net

Baras, E., \& Jobling, M. (2002). Dynamics of intracohort cannibalism in cultured fish. Aquaculture Research, 33, 461-479. https://doi.org/10.1046/j.1365-2109.2002.00732.x

Baras, E., Kestemont, P., \& Mélard, C. (2003). Effect of stocking density on the dynamics of cannibalism in sibling larvae of Perca fluviatilis under controlled conditions. Aquaculture, 219, 241-255. https://doi.org/ 10.1016/S0044-8486(02)00349-6

Borla, M. A., Palecek, B., Budick, S., \& O’Malley, D. M. (2002). Prey capture by larval zebrafish: Evidence for fine axial motor control. Brain, Behavior and Evolution, 60, 207-229. https://doi.org/10.1159/000066699

Browne, R. A., Sorgeloos, P., \& Trotman, C. N. A. (1991). Artemia biology. Boca Raton, FLA, USA: CRC Press.

Busch, K. E. T., Falk-Petersen, I. B., Peruzzi, S., Rist, N. A., \& Hamre, K. (2010). Natural zooplankton as larval feed in intensive rearing systems for juvenile production of Atlantic cod (Gadus morhua L.). Aquaculture Research, 41, 1727-1740. https://doi.org/10.1111/j.1365-2109.2009.02450.x

Busch, K. E. T., Peruzzi, S., Tonning, F., \& Falk-Petersen, I. B. (2011). Effect of prey type and size on the growth, survival and pigmentation of cod (Gadus morhua, L.) larvae. Aquaculture Nutrition, 17, $595-603$. https://doi.org/10.1111/j.1365-2095.2010.00800.x

Cahu, C. L., \& Zambonino Infante, J. L. (1994). Early weaning of sea bass (Dicentrarchus labrax) larvae with a compound diet: Effect on digestive enzymes. Comparative Biochemistry Physiology, Part A, 109, $213-222$. https://doi.org/10.1016/0300-9629(94)90123-6

Detrich, H. W., Zon, L. I., \& Westerfield, M. (2009). Essential Zebrafish Methods: Genetics and Genomics. London, UK, Academic Press.

Dhont, J., \& Dierckens, K., Støttrup, J. G., Van Stappen, G., Wille, M., \& Sorgeloos, P. (2013). Rotifers, artemia and copepods as live feeds for fish larvae in aquaculture. In G. Allan \& G. Burnell (Eds.), Advances in Aquaculture Hatchery Technology (pp. 157-202). Sawston, Cambridge, UK, Woodhead Publishing. https://doi.org/10.1533/9780857097460.1.157

Egloff, M. (1996). Failure of swim bladder inflation of perch, Perca fluviatilis L. found in natural populations. Aquatic Sciences, 58, 15-23. https://doi.org/10.1007/BF00877637

Fokin, S. (1997). Morphological diversity of the micronuclei in Paramecium. Archiv für Protistenkunde, 148, 375-387. https://doi.org/10.1016/S0003-9365(97)80017-6

Grotmol, S., Kryvi, H., \& Totlan, G. K. (2005). Deformation of the notochord by pressure from the swim bladder may cause malformation of the vertebral column in cultured Atlantic cod Gadus morhua larvae: A case study. Diseases of Aquatic Organisms, 65, 121-128. https://doi.org/10.3354/dao065121

Hamre, K., Yúfera, M., Rønnestad, I., Boglione, C., Conceição, L. E. C., \& Izquierdo, M. (2013). Fish larval nutrition and feed formulation: Knowledge gaps and bottlenecks for advances in larval rearing. Reviews in Aquaculture, 5, S26-S58. https://doi.org/10.1111/j.1753-5131.2012.01086.x

Jacquemond, F. (2004) Separated breeding of perch fingerlings (Perca fluviatilis L.) with and without initial inflated swim bladder: Comparison of swim bladder development, skeleton deformation and growth performance. Aquaculture, 239, 261-273. https://doi.org/10.1016/j.aquaculture.2004.06.019

Jentoft, S., Øxnevad, S., Aastveit, A. H., \& Andersen, Ø. (2006). Effects of tank wall color and up-welling water flow on growth and survival of Eurasian perch larvae (Perca fluviatilis). Journal of the World Aquaculture Society, 37, 313-317. https://doi.org/10.1111/j.1749-7345.2006.00042.x

Kestemont, P., Dabrowski, K., \& Summerfelt, R. (2015). Biology and Culture of Percid Fishes: Principles and Practices. Berlin, Springer.

Kestemont, P., Jourdan, S., Houbart, M., Mélard, C., Paspatis, M., Fontaine, P., ... Baras, E. (2003). Size heterogeneity, cannibalism and competition in cultured predatory fish larvae: Biotic and abiotic influences. Aquaculture, 227, 333-356. https://doi.org/10.1016/S0044-8486(03)00513-1

Kestemont, P., Xueliang, X., Hamza, N., Maboudou, J., \& Toko, I. I. (2007). Effect of weaning age and diet on pikeperch larviculture. Aquaculture, 264, 197-204. https://doi.org/10.1016/j.aquaculture.2006.12.034

King, N. J., \& Nardi, C. (2002). Hatchery production of Atlantic cod: Addressing nitrogen, oxygen and total gas pressure during larviculture. Bulletin of the Aquaculture Association of Canada, 102, 12-17. 
Kratochvil, M., Peterka, J., Kubečka, J., Matěna, J., Vašek, M., Vaničková, I., ... Seda, J. (2008). Diet of larvae and juvenile perch, Perca fluviatilis performing diel vertical migrations in a deep reservoir. Folia Zoologica, 57, 313-323.

Król, J., \& Zieliński, E. (2015). Effects of stocking density and weaning age on cannibalism, survival and growth in European perch Perca fluviatilis larvae. Polish Journal of Natural Sciences, 30, 403-415.

Lahnsteiner, F. (2017). Digestive enzyme system of larvae of different freshwater teleosts and its differentiation during the initial phase of exogenous feeding. Czech Journal of Animal Science, 62, 403-416. https://doi.org/ 10.17221/25/2016-CJAS

Lahnsteiner, F., \& Kletzl, M. (2015a). On-feeding and juvenile production of coregonid species with formulated dry feeds: Effects on fish viability and digestive enzymes. Journal of Agricultural Science, 7(1), 48-58. https://doi.org/10.5539/jas.v7n11p48

Lahnsteiner, F., \& Kletzl, M. (2015b). Suitability of different food types for on-feeding and juvenile production of European grayling, Thymallus thymallus, under intensive farming conditions. Journal of Agricultural Science, 7(11), 161-168. https://doi.org/10.5539/jas.v7n1p161

Lahnsteiner, F., \& Kletzl, M. (2017) Weaning of burbot, Lota lota (L.) from live to dry feed using $\mathrm{NaCl}$ as dietary attractant. Journal of Agricultural Science, 9(3), 7-18. https://doi.org/10.5539/jas.v9n3p7

Lewis, D. M., \& Pedley, T. J. (2001).The influence of turbulence on plankton predation strategies. Journal of Theoretical Biology, 210, 347-365. https://doi.org/10.1006/jtbi.2001.2310

Lopez, L. C. S., Gonçalves, D. A., Mantovani, A., \& Rios, R. I. (2002). Bromeliad ostracods pass through amphibian (Scinax perpusillus) and mammalian guts alive. Hydrobiologia, 485, 209-211. https://doi.org/ 10.1023/A:1021315223774

Lubens, E., Zmora, O., \& Barr, Y. (2001). Biotechnology and aquaculture of rotifers. Hydrobiologia, 446/447, 337-353. https://doi.org/10.1023/A:1017563125103

Majoris, J. E., Francisco, F. A., Atema, J., \& Buston, P. M. (2018). Reproduction, early development, and larval rearing strategies for two sponge-dwelling neon gobies, Elacatinus lori and E. colini. Aquaculture, 483, 286-295. https://doi.org/10.1016/j.aquaculture.2017.10.024

Mélard, C., Baras, E., Mary, L., \& Kestemont, P. (1996). Relationships between stocking density, growth, cannibalism and survival rate in intensively cultured larvae and juveniles of perch (Perca fluviatilis). Annales Zoologici Fennici, 33, 643-651.

Mélard, C., Kestemont, P., \& Grignard, J. C. (1996). Intensive culture of juvenile and adult Eurasian perch (P. fluviatilis): Effect of major biotic and abiotic factors on growth. Journal of Applied Ichthyology, 12, 175-180. https://doi.org/10.1111/j.1439-0426.1996.tb00085.x

Müller, T., Pál, L., Bódis, M., Kucska, B., Wágner, L., Bercsényi, M., ... Molná, T. (2012). Effect of dietary fat replacement on body composition of intensively reared hybrids of pikeperch and Volga pikeperch. The Israeli Journal of Aquaculture-Bamidgeh, 64, 1-7.

Munson, B. R., Huebsch, W. W., \& Rothmayer, A. P. (2012). Fundamentals of Fluid Mechanics. Hoboken, New Jersey, USA, John Wiley \& Sons Inc.

Ostaszewska, T., Dabrowski, K., Czumińska, K., Olech, W., \& Olejniczak, M. (2005). Rearing of pike-perch larvae using formulated diets-First success with starter feeds. Aquaculture Resarch, 36, 1167-1176. https://doi.org/10.1111/j.1365-2109.2005.01332.x

Pantazis, P. A., Benekos, G., \& Papadomichelakis, G. (2014). Early-weaning diets for gilthead sea bream (Sparus aurata L.) and their potential use in Hellenic marine fish hatcheries. Aquaculture International, 22, 1621-1636. https://doi.org/10.1007/s10499-014-9769-3

Park, H. G., Puvanendran, V., Kellett, A., Parris, C. C., \& Brown, J. A. (2006). Effect of enriched rotifers on growth, survival, and composition of larval Atlantic cod (Gadus morhua). ICES Journal of Marine Science, 63, 285-295. https://doi.org/10.1016/j.icesjms.2005.10.011

Pedrazzani, A. S., Pham, N. K., Lin, J., \& Neto, A. O. (2014). Reproductive behavior, embryonic and early larval development of the red head goby, Elacatinus puncticulatus. Animal Reproduction Science, 145(1-2), 69-74. https://doi.org/10.1016/j.anireprosci.2013.12.013

Peruzzi, S., Westgaard, J. I., \& Chatain, B. (2007). Genetic investigation of swimbladder inflation anomalies in the 
European sea bass, Dicentrarchus labrax L. Aquaculture, 265, 102-108. https://doi.org/10.1016/ j.aquaculture.2006.10.029

Peterson, T. S., Ferguson, J. A., Watral, V. G., Mutoji, K. N., Ennis, D. G., \& Kent, M. L. (2013). Paramecium caudatum enhances transmission and infectivity of Mycobacterium marinum and Mycobacterium chelonae in zebrafish (Danio rerio). Diseases of Aquatic Organisms, 106, 229-239. https://doi.org/10.3354/dao02649

Policar, T., Samarin, A. M., \& Mélard, C. (2015). Culture methods of Eurasian perch during ongrowing. In P. Kestemont, K. Dabrowski, \& R. C. Summerfelt (Eds.), Biology and Culture of Percid Fishes (pp. 417-437). Dordrecht, NL, Springer Science Business Media. https://doi.org/10.1007/978-94-017-7227-3_16

Quevauviller, P., \& Thompson, K. C. (2006). Analytical Methods for Drinking Water-Advances in Sampling and Analysis. Chichester, UK, Wiley.

Rekecki, A., Meeus, W., Chiers, K., Adriaen, J., Boyen, F., Declercq, A., ... Decostere, A. (2016). Swimbladder hyperinflation in burbot Lota lota L. larvae. Aquaculture Research, 47, 673-676. https://doi.org/10.1111/ are.12499

Ribi, G. (1992). Perch larvae (Perca fluviatilis L.) survive better in dilute sea water. Aquatic Sciences, 54, 85-90. https://doi.org/10.1007/BF00877266

Shiri Harzevili, A., De Charleroy, D., Auwerx, J., Vught, I., Van Slycken, J., Dhert, P., \& Sorgeloos, P. (2003). Larval rearing of burbot (Lota iota L.) using Brachionus calyciflorus rotifer as starter food. Journal of Applied Ichthyology, 19, 84-87. https://doi.org/10.1046/j.1439-0426.2003.00442.x

Skrzypczak, A., Mamcarz, R., Kujawa, R., Kucharczyk, D., \& Furgala-Selezniow, G. (1998). Feeding habits of larval Eurasian perch, Perca fluviatilis (Percidae). Italian Journal of Zoology, 65, 243-245. https://doi.org/10.1080/11250009809386825

Støttrup, J. G. (2003). Production and nutritional value of copepods. In J. G. Støttrup \& L. A. McEvoy (Eds.), Live Feeds in Marine Aquaculture (pp. 145-205). Oxford, UK, Blackwell Science. https://doi.org/10.1002/ 9780470995143.ch5

Szkudlarek, M., \& Zakęś, Z. (2007). Effect of stocking density on survival and growth performance of pikeperch, Sander lucioperca (L.), larvae under controlled conditions. Aquaculture International, 15, 67-81. https://doi.org/10.1007/s10499-006-9069-7

Tamazouzt, L., Chatai, B., \& Fontaine, P. (2000). Tank wall colour and light level affect growth and survival of Eurasian perch larvae (Perca fluviatilis L.) Aquaculture, 182, 85-90. https://doi.org/10.1016/S0044-8486 (99)00244-6

Tamazouzt, L., Leray, C., Escaffre, A. M., \& Terver, D. (1998). Effects of food particle size on Perca fluviatilis larval growth. Aquatic Sciences, 60, 89-98. https://doi.org/10.1007/PL00001316

Treasurer, J. W. (1992). The predator-prey relationship of perch, Perca fluviatilis, larvae and zooplankton in two Scottish lochs. Environmental Biology of Fishes, 35, 63-74. https://doi.org/10.1007/BF00001159

Trotter, A. J., Pankhurst, P. M., \& Hart, P. R. (2001). Swim bladder malformation in hatchery-reared striped trumpeter Latris lineata (Latridae). Aquaculture, 198, 41-54. https://doi.org/10.1016/S0044-8486(00) 00594-9

Vlavonou, R. S., Masson, G., \& Moreau, J. C. (1999). Growth of Perca fluviatilis larvae fed with Artemia spp. nauplii and the effects of initial starvation. Journal of Applied Ichthyology, 15, 29-33. https://doi.org/ 10.1046/j.1439-0426.1999.00096.x

Woolley, L. D., \& Qin, J. G. (2010). Swimbladder inflation and its implication to the culture of marine finfish larvae. Reviews in Aquaculture, 2, 181-190. https://doi.org/10.1111/j.1753-5131.2010.01035.x

\section{Copyrights}

Copyright for this article is retained by the author (s), with first publication rights granted to the journal.

This is an open-access article distributed under the terms and conditions of the Creative Commons Attribution license (http://creativecommons.org/licenses/by/4.0/). 